\title{
KOMPETENSI, KEPEMIMPINAN, DISIPLIN KERJA TERHADAP KINERJA KARYAWAN HUMAN RESOURCES AND FACILTY MANAGEMENT DIRECTORATE
}

\author{
SETIA TJAHYANTI \\ NURAFNI CHAIRUNNISA \\ Trisakti School of Management, Jl. Kyai Tapa No. 20, Grogol, Jakarta, Indonesia \\ setia@stietrisakti.ac.id
}

\begin{abstract}
The purpose of this study was to determine the effect of several variables such as competence, leadership, and work discipline on employee performance. The method used is descriptive and causality. The statistical test in this study uses Multiple Regression Analysis. Respondents involved in this study were 82 employees who were permanent employees at the Human Resources and Facility Management Directorate at PT Gramedia Asri Media, Jakarta Head Office. The sampling method of this research is using purposive sampling. Data collection techniques using questionnaires and interviews. Data analysis was performed using multiple regression. The results showed that partially competence has an effect on employee performance, leadership does not affect employee performance, work discipline affects employee performance.
\end{abstract}

Keywords: : Competence, leadership, work discipline, employee performance

Abstrak: Tujuan penelitian ini adalah untuk mengetahui pengaruh dari beberapa variabel seperti, Kompetensi, Kepemimpinan, dan Disiplin Kerja terhadap Kinerja Karyawan. Metode yang digunakan adalah Deskriptif dan Kausalitas. Pengujian statistik dalam penelitian ini menggunakan Analisis Regresi Berganda. Responden yang terlibat dalam penelitian ini berjumlah 82 karyawan yang merupakan karyawan tetap pada Human Resources and Facility Management Directorate pada PT Gramedia Asri Media Kantor Pusat Jakarta. Metode sampling penelitian ini menggunakan Sampling Purposive. Teknik pengumpulan data dengan menggunakan kuesioner dan wawancara. Analisis data yang dilakukan dengan menggunakan regresi berganda. Hasil penelitian menunjukan bahwa secara parsial Kompetensi berpengaaruh terhadap Kinerja Karyawan, Kepemimpinan tidak mempengaruhi Kinerja Karyawan, Disiplin Kerja berpengaruh terhadap Kinerja Karyawan.

Kata Kunci: Kompetensi, kepemimpinan, disiplin kerja, kinerja karyawan

\section{PENDAHULUAN}

Dunia yang semakin hari semakin berkembang menuntut manusia untuk maju mengikuti perkembangan yang ada. Tidak bisa dipungkiri, manusia sebagai makhluk sosial membutuhkan informasi untuk menambah pengetahuan mereka sehingga diharapkan kemajuan yang diharapkan dapat terwujud. Selain itu, pengetahuan dan informasi juga memegang peranan penting bagi kemajuan dalam segala bidang. Berbagai informasi yang diperlukan tersebut bisa diperoleh dari berbagi sumber, salah satunya adalah buku. Buku menjadi pusat informasi dan ilmu pengetahuan bagi semua orang. Berbagai teknologi canggih 
pengakses informasi seperti laptop, i-pad, iphone, dan lainnya terus bermunculan. Namun, buku tetap menjadi pilihan utama sebagai sumber informasi. Hal ini dapat kita lihat dengan banyaknya buku-buku baru yang terus terbit untuk menjawab dan memenuhi kebutuhan konsumen akan informasi dan ilmu pengetahuan. Salah satunya PT Gramedia Asri Media yang merupakan anak perusahaan Kompas Gramedia yang menyediakan jaringan toko buku dengan nama Toko Buku Gramedia di beberapa kota di Indonesia. Perusahaan ini didirikan pada tanggal 2 Februari 1970 dengan diawali dari satu toko buku kecil berukuran 25 m2 di daerah Jakarta Barat.

Kinerja pegawai dalam sebuah organisasi memiliki peranan yang sangat penting untuk dapat membantu organisasi dalam mencapai Visi dan Misi yang telah ditetapkan perusahaan. Penilaian kinerja selalu mengasumsikan bahwa karyawan memahami apa standar kinerja mereka, dan penyelia juga memberikan karyawan 4 umpan balik, pengembangan, dan insentif yang diperlukan untuk membantu orang yang bersangkutan menghilangkan kinerja yang kurang baik atau melanjutkan kinerja yang baik (Dessler 2017, 322). Menurut Robbins dan Coulter $(2018,637)$ menyatakan bahwa "Performance is the end resulf of an activity" Kinerja karyawan adalah hasil dari akhir sebuah aktivitas yang dilakukan karyawan Perkembangan PT Gramedia Asri Media dari tahun ke tahun dapat diukur pula dengan melihat kinerja karyawannya. Salah satu yang mempengaruhi kinerja adalah kompetensi. Kompetensi bagi beberapa profesi menjadi persyaratan penting dalam menjalankan kerangka dan tujuan organisasi. Salah satu indikator dari Kepemimpinan adalah pengambilan keputusan. Menurut Chapman (Gitosudarmo dan Sudita dalam Sunyoto, 2015:31) Pengambilan keputusan adalah membuat pilihan dari dua atau lebih alternatif. Berdasarkan hasil wawancara dengan Manajer Human Resources Division terkait dengan pengambilan keputusan yang diterapkan di perusahaan adalah demokratis, bahwa adanya keseimbangan dalam berperan aktif antara pemimpin dengan bawahan dalam pengambilan keputusan. Teguran dan Hukuman yang berlaku pada PT Gramedia Asri Media berlaku untuk semua karyawan. Implementasi selama ini 10 berdasarkan hasil wawancara dengan salah satu Superintendent di Human Resources Division bahwa jika ada karyawan yang bermasalah maka di hubungi melalui telepon terlebih dahulu yaitu dengan menghubungi atasan dari karyawan tersebut untuk mengkonfirmasi masalah yang terjadi. Hal ini diterapkan karena PT Gramedia Asri Media mengupayakan untuk meningkatkan Disiplin Kerja terhadap semua karyawan. Human Resources and Facility Management Directorate pada PT Gramedia Asri Media Kantor Pusat Jakarta memiliki Disiplin Kerja yang baik, hal itu dapat dilihat berdasarkan jumlah pelanggar selama tiga tahun terakhir. Jumlah pelanggar selama tiga tahun terakhir < 10 karyawan. Berdasarkan Tabel 1.4 jenis pelanggaran yang terjadi dari hasil wawancara yaitu karyawan yang bermasalah dengan kehadiran. Penelitian ini merupakan replikasi penelitian dari Slamet Ahmadi, Sulistyono (2018) yang berjudul "Pengaruh Kompetensi, Kepemimpinan, dan Disiplin Kerja terhadap Kinerja Pegawai" penelitian sebelumnya menggunakan Kantor Pertanahan Kabupaten Bogor, sedangkan penulis menggunakan Human Resources and Facility Management Directorate pada PT Gramedia Asri Media 11 Kantor Pusat Jakarta sebagai obyek penelitian dan sampel yang akan digunakan dalam penelitian ini berjumlah 82 orang. Beberapa alasan mengapa peneliti menggunakan Human Resources and Facility Management Directorate PT Gramedia Asri Media Kantor Pusat Jakarta sebagai obyek penelitian, antara lain: 1. Adanya kesenjangan antara penelitian sebelumnya yang dilakukan oleh Rommy Beno Rumondor, Altje Tumbel, dan Jantje L. Sepang(2016) dinyatakan bahwa 
Kepemimpinan memliki pengaruh secara signifikan terhadap Kinerja Karyawan. Sedangkan hasil penelitian yang dilakukan oleh Slamet Ahmadi, Sulistyono (2018) dinyatakan bahwa Kepemimpinan tidak berpengaruh secara signifikan terhadap Kinerja Karyawan. 2. Penulis memilih PT Gramedia Asri Media khususnya pada divisi human resources karena divisi ini memiliki keunggulan dibandingkan divisi lain keunggulan tersebut adalah salah satu divisi yang mempunyai/menciptakan usaha baru, yaitu childcare yang bernama "Wimili" yang berlokasi di Bintaro Sektor 9. Divisi human resources juga meraih penghargaan inovasi terbaik dalam Gramedia Awards 2018 dan mendapatkan penghargaan menjadi divisi terbaik selama 3 tahun terakhir. 3. Penulis ingin mengetahui bukti empiris mengenai seberapa besar pengaruh Kompetensi, Kepemimpinan dan Disiplin Kerja Terhadap Kinerja Karyawan Human Resources and Facility Management Diractorate pada PT Gramedia Asri Media Kantor Pusat Jakarta. 12 Berdasarkan latar belakang penelitian yang telah diuraikan, maka akan dilakukan penelitian dengan judul "Pengaruh Kompetensi, Kepemimpinan dan Disiplin Kerja Terhadap Kinerja Karyawan Human Resources and Facility Management Diractorate pada PT Gramedia Asri Media Kantor Pusat Jakarta".

Kompetensi Menurut Dessler (2017:408) kompetensi adalah karakteristik pribadi yang dapat ditunjukan seperti pengetahuan, keterampilan dan perilaku pribadi seperti kepemimpinan. Wibowo (2016:271) mengemukakan bahwa suatu kemampuan untuk melaksanakan atau melakukan suatu pekerjaan atau tugas yang dilandasi atas keterampilan dan pengetahuan serta didukung oleh sikap kerja yang dituntut oleh pekerjaan itu tersebut. Menurut Edison,Anwar dan Komariyah (2016:142) Kompetensi adalah kemampuan individu untuk melaksanakan suatu pekerjaan dengan benar dan memiliki keunggulan yang didasarkan pada hal-hal yang menyangkut pengetahuan (Knowledge), keahlian (skill), dan sikap (attitude). Dari ketiga definisi yang dikemukakan oleh para ahli tentang kompetensi maka dapat disimpulkan bahwa kompetensi merupakan kemampuan dan karakterisitik seseorang dalam melakukan pekerjaan atau tugas yang dilandasi atas pengetahuan, keterampilan dan perilaku yang dimiliki individu dengan efektifitas. 17 2.1.1.1. Manfaat Pengembangan Kompetensi Menurut Moeheriono (2014:8) menyatakan perkembangan sistem kompetensi pada setiap organisasi harus dikembangkan seluas-luasnya dalam rangka mengembangkan manajemen sumber daya manusianya. Berikut ini adalah manfaat dan keuntungan dalam pengembangan kompetensi: Dapat dipakai menjadi acuan kesuksesan awal bekerja seseorang. Model kompetensi ini dapat menentukan dengan tepat pengetahuan dan keterampilan apa saja yang dibutuhkan untuk keberhasilan dalam pekerjaan tersebut. Dapat dipakai sebagai dasar untuk merekrut karyawan yang baik dan andal. Apabila sudah berhasil ditentukan kompetensikompetensi apa saja yang diperlukan bagi suatu posisi tertentu, maka dengan mudah dapat dijadikan sebagai kriteria dasar dalam rekrutmen karyawan baru. Dapat dipakai sebagai dasar penilaian dan pengembangan karyawan selanjutnya. Hasil identifikasi kompetensi pekerjaan yang akurat dapat juga dipakai sebagai tolak ukur kemampuan seseorang. Dapat dipakai sebagai dasar penilaian kinerja dan pemberian kompensasi bagi karyawan berprestasi atas hukuman bagi karyawan yang tidak berpestasi. Pihak manajemen bias menarik kesimpulan bahwa kompetensi sangat bermanfaat untuk Training Need Analysis. Diharapkan bahwa dasar pemberian training lebih beralasan dan sesuai kebutuhan karyawan dan organisasi.

Kepemimpinan Robbin (2017, 420) "leadership as the ability to influence a group toward the achievement of a vision or set of goals". Kepemimpinan merupakan kemampuan untuk mempengaruhi suatu kelompok guna tercapainya visi dan tujuan perusahaan. Daft $(2015,5)$ "leadership an influence relationship 
among leaders and followers intend real changes and outcomes that reflect their shared purposed". Kepemimpinan merupakan pengaruh suatu hubungan antara pemimpin dan pengikut yang berniat untuk melakukan perubahan nyata dan dengan hasil yang mencerminkan tujuan bersama atau organisasi. Hasibuan $(2014,170)$ kepemimpinan adalah cara seorang pemimpin mempengaruhi bawahan, agar mau bekerja sama dan bekerja secara produktif untuk mencapai tujuan organisasi. Berdasarkan konsep yang telah dijelaskan mengenai pengaruh Kompetensi, Kepemimpinan dan Disiplin Kerja terhadap Kinerja Karyawan melihat kepada hasil peneliti terdahulu, maka dibuatlah model penelitian sebagai berikut :

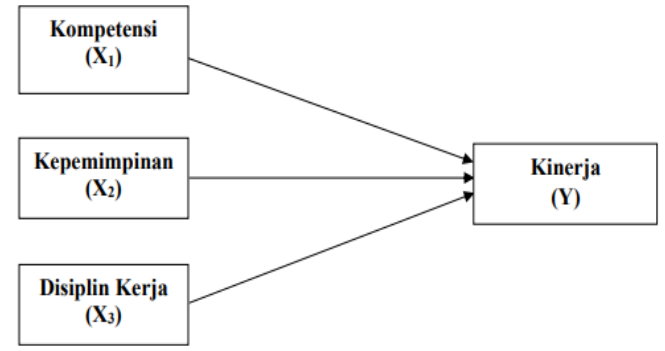

Gambar 1 Model penelitian

\section{METODE PENELITIAN}

Bentuk penelitian yang akan dilakukan dalam penelitian ini adalah deskriptif dan kausalitas. "Descriptive studies are often designed to collect data that describe characteristics of object (such as persons, organization, product, or brands), events, or situation." (Sekaran and Bougie 2016, 43). Sehingga dapat dikatakan studi deskriptif adalah dibuat untuk mengumpulkan data yang akan menggambarkan karakteristik dari obyek seperti orang, organisasi, kejadiankejadian, dan situasi. Obyek yang digunakan dalam penelitian ini adalah Karyawan tetap Human Resources and
Facility Management Directorate PT Gramedia Asri Media Kantor Pusat yang berlokasi di Jl. Palmerah Barat No.29-37, RT.1/RW.2, Gelora, Tanah Abang, Kota Jakarta Pusat, Daerah Khusus Ibukota Jakarta 10270.

\section{HASIL DAN PEMBAHASAN}

Dalam penelitian ini digunakan teknik non-probability sampling dengan teknik sampling purposive, dimana kuesioner dibagikan kepada seluruh karyawan tetap Human Resources and Facility Management Directorate pada PT Gramedia Asri Media Kantor Pusat Jakarta. Kuesioner tersebut kemudian akan dianalisis dan digunakan untuk pengujian statistik menggunakan aplikasi IBM SPSS 23. Data yang diperoleh berupa karakteristik responden yang berisikan data karyawan. Total karyawan Human Resources and Facility Management Directorate pada PT Gramedia Asri Media Kantor Pusat Jakarta berjumlah 109 orang. Dengan penjabaran karyawan tetap 88 orang dan karyawan tidak tetap 21 orang. Jumlah populasi dalam penelitian ini sebanyak 88 orang dan sampel yang digunakan adalah 82 orang. Berikut adalah penjabaran data dalam penelitian ini:

Karakteristik responden merupakan data-data pribadi tentang responden yang meliputi Usia, Jenis Kelamin, Pendidikan Terakhir dan Masa Kerja responden. Jumlah responden berusia 20-25 tahun berjumlah 2 orang, responden berusia 26-30 tahun berjumlah 12 orang, responden berusia 31-35 tahun berjumlah 24 orang, responden berusia 36-40 tahun berjumlah 35 orang, dan responden berusia $>41$ tahun berjumlah 9 orang. Diketahui nilai rata-rata variabel kinerja karyawan adalah sebesar 3,46 yang memperlihatkan bahwa mayoritas responden netral dengan pertanyaan pada variabel kinerja karyawan. 


\begin{tabular}{ccccc}
\multicolumn{6}{c}{ Tabel 4.10 } \\
Hasil Uji Validitas Variabel Kompetensi $\left(\mathbf{X}_{1}\right)$ \\
\hline Variabel & Item & r hitung & r tabel & Validitas \\
\hline Kompetensi $\left(\mathbf{X}_{1}\right)$ & KO1 & 0,704 & 0,2172 & Valid \\
& KO2 & 0,527 & 0,2172 & Valid \\
& KO3 & 0,490 & 0,2172 & Valid \\
& KO4 & 0,557 & 0,2172 & Valid \\
& KO5 & 0,641 & 0,2172 & Valid \\
& KO6 & 0,488 & 0,2172 & Valid \\
& KO7 & 0,431 & 0,2172 & Valid \\
& KO8 & 0,507 & 0,2172 & Valid \\
& KO9 & 0,464 & 0,2172 & Valid \\
& KO10 & 0,547 & 0,2172 & Valid \\
& KO11 & 0,599 & 0,2172 & Valid \\
& KO12 & 0,565 & 0,2172 & Valid \\
\hline
\end{tabular}

Pada penelitian ini, nilai $r$ tabel dicari pada signifikansi 2-tailed 0,05 atau $5 \%$ dan jumlah responden $(n)=82$, dengan $d f=80$ sehingga $r$ tabel yang didapat adalah 0,2172 . Dari tabel di atas menunjukan bahwa seluruh nilai $r$ hitung indikator Kepemimpinan (X2) lebih besar dari pada $r$ tabel, maka seluruh item tersebut dapat dikatakan valid dan dapat dijadikan sebagai alat pengumpul data penelitian.

Pada penelitian ini, nilai $r$ tabel dicari pada signifikansi 2-tailed 0,05 atau $5 \%$ dan jumlah responden $(n)=82$, dengan $\mathrm{df}=80$ sehingga $r$ tabel yang didapat adalah 0,2172. Dari tabel di atas menunjukan bahwa seluruh nilai r hitung indikator 70 Disiplin Kerja (X3) lebih besar dari pada $r$ tabel, maka seluruh item tersebut dapat dikatakan valid dan dapat dijadikan sebagai alat pengumpul data penelitian. Menyatakan bahwa variabel Kompetensi (X1) memiliki nilai Cronbach's Alpha sebesar 0,862, variabel Kepemimpinan (X2) memiliki nilai Cronbach's Alpha sebesar 0,912, variabel Disiplin Kerja (X3) memiliki nilai Cronbach's Alpha sebesar 0,867 dan variabel Kinerja Karyawan ( $Y$ ) memiliki nilai Cronbach's Alpha sebesar 0,870 sehingga dapat disimpulkan bahwa seluruh variabel dalam penelitian ini adalah reliabel, yang berarti pernyataan dalam penelitian ini menghasilkan jawaban yang konsisten dari waktu ke waktu dan setiap pernyataan tersebut dapat digunakan dalam penelitian ini.
Diketahui nilai $p$-value (sig) dan nilai signifikan lebih kecil dari alpha yaitu sebesar $0,001<0,05$ sehingga kesimpulannya terdapat pengaruh yang signifikan kompetensi terhadap kinerja karyawan Human Resources and Facility Management Directorate pada PT. Gramedia Asri Media Kantor Pusat .

Diketahui nilai $p$-value (sig) dan nilai signifikan lebih besar dari alpha yaitu sebesar 0,323>0,05 sehingga kesimpulannya tidak terdapat pengaruh yang signifikan kepemipinan terhadap kinerja karyawan Human Resources and Facility Management Directorate pada PT. Gramedia Asri Media Kantor Pusat Jakarta.

Diketahui nilai $p$-value (sig) dan nilai signifikan lebih kecil dari alpha yaitu sebesar $0,000<0,05$ sehingga kesimpulannya terdapat pengaruh yang signifikan Disiplin Kerja terhadap kinerja karyawan Human Resources and Facility Management Directorate pada PT. Gramedia Asri Media Kantor Pusat Jakarta.

\section{PENUTUP}

Berdasarkan bab sebelumnya yang membahas mengenai hasil analisis pengujian statistik menggunakan SPSS versi 23 yang dilakukan Human Resources and Faciity Management Directorate pada PT.Gramedia Asri Media Kanttor Pusat Jakarta dengan alamat di Jl. Palmerah Barat No.29-37, RT.1/RW.2, Gelora, Tanah Abang, Kota Jakarta Pusat, Daerah Khusus Ibukota Jakarta 10270. 
Penelitian ini menganalisis pengaruh variabel independen yaitu Kompetensi (X1) Kepemimpinan (X2) dan Disiplin Kerja (X3) terhadap variabel dependen yaitu Kinerja Karyawan $(\mathrm{Y})$.

\section{REFERENCES:}

Ahmadi, Slamet., Sulistyono.2018. Pengaruh Kompetensi, Kepemimpinan dan Disiplin Kerja terjadap Kinerja Pegawai di Kantor Pertanahan Kabupaten Bogor.,Jurnal Manajemen Kewirausahaan, 15(02).

Coulter, Mary., Stephen P. Robbins. 2018. Management. Fourteenth Edition, Global Edition: Pearson.

Daft, Richard L. 2015. The Leadership Experience. Canada: Cengage Learning.

Dessler, Gary. 2017. Human Resource Management. England: Pearson Education Limited, Inc.

Edison,Emron,Yohny Anwar,Imas Komariyah.2016.Manajemen Sumber Daya Manusia.Alfabeta:Bandung Hasibuan, Melayu SP. 2014. Manajemen Sumber Daya Manusia. Jakarta: PT Bumi Aksara

Hoke, Steward V.,Bernhard Tewal.,Jacky S.B Sumaraw.2018. Pengaruh Kompetensi,Komitmen Organisasi dan Kompensasi terhadap Kinerja Karyawan PT.Marga Dwitaguna Manado Sulawesi Utara.,Jurnal EMBA,6 (1), 1-10.

Newstorm, John W. 2015. Organizational Behavior, Human Behavior at Work. Fourteenth Edition. Hill International Edition.

Rivai, Veuthzal. 2015. Manajemen Sumber Daya Manusia untuk Perusahaan dari Teori ke Praktik. Jakarta: PT Raja Grafindo Persada

Robbins, Stephen P., Timothy A. Judge. 2019. Organizational Behavior.Eighteenth Edition. England:Pearson. 2017. Organizational Behavior. Sixteenth Edition. England:

Pearson Rue, Leslie W., Nabil A. Ibrahim., Lloyd L. Byars. 2016. Human Resources Management. Eleventh Edition. United Kingdom: Hill International Edition.

Rumondor, Tumbel, Sepang. 2016. Pengaruh Kepemimpinan, Motivasi, dan Disiplin Kerja Terhadap Kinerja Pegawai Pada Kanwil Ditjen Kekayaan Negara Suluttenggomalut. Jurnal EMBA, 4(2), 254- 264

Sekaran, Uma, and Roger Bougie. 2013. Research Methods For Business. 6th Edition. United Kingdom: John Wiley \& Sons, Ltd. 